\title{
Risk patterns, structural characteristics, and organizational configurations*
}

\author{
Antonio Renzi | Giuseppe Sancetta | Beatrice Orlando
}

\author{
University "La Sapienza" of Rome, Italy \\ Correspondence \\ Beatrice Orlando, Sapienza University of \\ Rome, Department of Management, Via del \\ Castro Laurenziano 9, Rome 00161, Italy \\ Email: beatrice.orlando@uniroma1.it
}

\begin{abstract}
A firm's structural characteristics are predictive of its risk pattern and attitude toward managing change over time. Idiosyncratic risk has its roots in the firm's structure. This affects the firm's volatility compared with the average volatility in the sector. Such characteristics and risk patterns affect the firm's capability to manage change and capture the value from change.
\end{abstract}

\section{1 | INTRODUCTION}

This study aims to examine the dynamics among the structural characteristics of a firm and its capability to manage change, capturing its value. To this end, we adopt the organizational configuration framework as a means to distinguish different patterns of structural characteristics, each marked by some peculiarities related to idiosyncratic risk dynamics. Consistently, we propose a novel conceptual approach. We consider the structural characteristics of a firm and its volatility compared with the average volatility within the sector. Thus, we depict a matrix that synthesizes the space of managerial maneuvers according to four types of possible organizational configuration within a single business sector. The matrix considers three firm dimensions: intrinsic business risk, structural instability, and the impact of both on the idiosyncratic unlevered risk. More insights on the endowment of slack resources are also offered. In fact, slack resources can function as a buffer to uncertainty. Each temporal dimension has a different hallmark of slack resources according to specific structural characteristics. Hence, they are consistent with each other in determining the risk pattern of the firm. For instance, an excess of absorbed slack increases a firm's rigidity, whereas conversely, available slack resources can be of use in development plans. The conceptual model is supported by an example of functioning in a small sample of firms operating in the European energy industry. Additionally, we used the sample to explore the validity of the model by conducting qualitative comparative analysis (QCA). The early test confirms the descriptive power of the matrix. The proposed conceptual framework has twofold relevance. In managerial terms, it offers a holistic representation of a

*JEL classification codes: L2, L7, M1. firm's configuration considering both risk and structural factors. At a practical level, the matrix can be used as an aid in managerial decision making, when the aim is to evaluate the firm's attitude toward change.

Idiosyncratic risk is risk that is specific to a particular firm (in opposition to systematic risk) and can be partially diversified through an adequate investment structure. It depends on the firm's endowment of resources and capabilities in a given time range. Thus, a firm's structure is the prime driver of idiosyncratic risk. It is said to be unlevered when it is considered in the absence of debt.

Idiosyncratic risk explains $80 \%$ of total equity risk (Gaspar \& Massa, 2006; Goyal \& Santa-Clara, 2003) and can inhibit strategic decisions because of uncertainty in future cash flow (Clayton, Hartzell, \& Rosenberg, 2005).

Numerous studies have investigated idiosyncratic risk dynamics, effects, and characteristics at the firm level (Bali, Cakici, Yan, \& Zhang, 2005; Brown \& Kapadia, 2007; Campbell, Lettau, Malkiel, \& Xu, 2001; Cao, Simin, \& Zhao, 2008; Ferreira \& Laux, 2007; Fu, 2009; Godfrey, 2005; Irvine \& Pontiff, 2009; Lee \& Faff, 2009; Mazzucato \& Tancioni, 2008; Panousi \& Papanikolaou, 2012; Pontiff, 2006).

However, to the best of our knowledge, there have been no previous attempts to link this topic with the organizational configurations approach, although many scholars focus on organizational structure. For instance, Grant (1996), embracing a resource-based approach, analyzes firms' idiosyncratic knowledge; earlier, Aiken and Hage (1968) identified some idiosyncratic elements, drivers of risk, analyzing organizational interdependence and intra-organizational structure.

Organizational configurations are described as archetypes of characteristics (Moores \& Yuen 2001), a combination of contingencies derived from the context (Child, 1973). The organizational configuration framework can offer a valid fuzzy approach to understand patterns of risk and firms' structural characteristics. 
At the core of this study is the impact of the structure on some environmental factors, such as the amount of exogenous risk actually absorbed by the firm. The structure also contributes to determining the inbound of intrinsic business risk; namely, that risk related to sector-specific characteristics. For instance, a firm's structure can either amplify the inbound of external risk or offer a sort of antibody protection compared with other firms operating in the same industry. In fact, lower volatility in cost and greater stability in revenues can lower idiosyncratic risk (Tuli \& Bharadwaj, 2009).

Implicitly, we assume both the path-dependent and evolutionary views of firms' development. According to the first view, past structures influence firms' future development. According to the second view, the structure impacts the possibility of future survival. For instance, high idiosyncratic risk can endanger a firm's survival (Hillier, Titman, \& Grinblatt, 1998). In terms of risk, this means that a firm's structure determines its risk profile, in both stationary and dynamic states. In each of the two states, the structure embeds some slack resources, which are resources in excess of the minimum necessary (Pondy, 1970). Such resources can either be a buffer to uncertainty or a rigidity factor, as a source of fixed costs.

The article is structured as follows. In Section 2, we relate the main literature antecedents. In Section 3, we propose our model. In Section 4, we use qualitative comparative analysis to explore the model consistency, using a small sample of companies operating in the European energy industry. Finally, in Sections 5 and 6, we interpret the relevance of this study and propose our conclusions.

\section{2 | LITERATURE ANTECEDENTS}

\section{1 | Organizational configurations}

An organizational configuration is a representation of a common pattern across firms (Fiss, 2007; Meyer, Tsui, \& Hinings, 1993); namely, it is a "multidimensional constellation of conceptually distinct characteristics that commonly occur together" (Meyer et al., 1993, p. 1175). This approach has its roots in and evolves from organizational theory and contingency theory, and it assumes the equifinality of organizations (Fiss, 2007), as well as the concept of strategic fit (Doty, Glick, \& Huber, 1993). According to Miller (1987), configurations are influenced by the environment, structure, leadership, and strategy.

Similarities occur at different levels (e.g., individual, group) and impact different aspects. Similarities in configurations can be verified, for instance, in relationships among components (Miller, 1987) or in imitation patterns related to social constructions (Berger \& Luckman, 1967).

Another key concern is the relationship between configurations and performance (Ketchen, Combs, Russell, Shook, Dean, Runge, \& Beckstein, 1997). Studies adopting the configuration approach can follow both deductive and inductive methods (Ketchen, Thomas, \& Snow, 1993). This approach is intended as a means to manage complexity, through depicting ideal typologies for the holistic interpretation of the dynamics of firms: it allows overcoming the excess of reductionism in the structural contingency approach (Meyer et al., 1993).
Organizational configurations allow the imposition of order and recognition of taxonomies, types, and patterns. An emblematic example of configurations is given by Mintzberg (1979), with his renowned work on the structure of organizations. More generally, taxonomies provided by scholars-with the use of multivariate empirical methods-are considered good examples of configurations (Meyer et al., 1993). In fact, archetypes have always been used in managerial studies to understand changes in firms (Greenwood \& Hinings, 1993). This method implicitly assumes the non-linearity of relationships, equifinality, and logic of chaos theory (Prigogine \& Stengers, 1984).

So far, structure has always been a core concern in organizational configurations (Meyer et al., 1993; Mintzberg, 1979), since it is the premise for fit and equifinality (Doty et al., 1993), and it affects structural change (Baker \& Cullen, 1993), as well as outcomes (Ketchen AQ1 et al., 1997; Pinto \& Curto, 2007; Quinn \& Rohrbaugh, 1993). Miller (1990) further argues that organizational configurations have predictive implications.

\section{2 | Resource slack}

A specific structure is the result of a series of investment decisions made over time. In any given structure, resources can be distinguished for being scarce or slack. Namely, slack resources are in excess of the minimum necessary (Antle \& Eppen, 1985; Kaldor, 1955; Pondy, 1970; Nohria \& Gulati, 1996; Seifert, Morris, \& Bartkus, 2004; Wernerfelt, 1984). More precisely, resource slack originates from contingencies, organizational characteristics, and values or beliefs of the dominant coalition (Sharfman, Wolf, Chase, \& Tansik, 1988). Other authors consider slack instead an exogenous variable (Bourgeois \& Singh, 1983). Although many typologies and taxonomies of slack have been created (Bourgeois, 1981; Cohen, March, \& Olsen, 1972; Cyert \& March, 1963; Moses, 1992), one useful way to categorize slack is distinguishing between high and low discretionary resources (Sharfman et al., 1988). In fact, the first category has a higher potential for firm growth, whereas the second category increases firm rigidity. Thus, not surprisingly, the impact of resource slack on performance is observed as an inverse u-shaped relationship (Nohria \& Gulati, 1996, 1997). Consistently, some authors (Child, 1972; Cyert \& March, 1963; Jensen, 1986; Thompson, 1967) argue that slack is bad, whereas others underscore its positive effect on performance (Singh, 1986) and its role as a buffer for risk and uncertainty (Aldrich, 1979; Cheng \& Kesner, 1997; Freeman, Carroll, \& Hannan, 1983).

According to Renzi (2011), resource slack increases the volatility of firms' outcomes: specifically, the operating slack interacts with the inbound of intrinsic business risk.

Many scholars link firm risk to structural variables, such as scale of production and industry concentration (O'Brien, 2011), firm size (Carroll \& Wei, 1988; Chan \& Chen, 1988; Handa, Kothari, \& Wasley, 1989), dynamics at the sector level (Vos, 1992), operating and financial leverage (Gahlon \& Gentry, 1982; Hill \& Stone, 1980; John, John, \& Reisman, 1994; Mandelker \& Rhee, 1984; Rubinstein, 1973), and intrinsic business risk (Chung, 1989; Griffin \& Dugan, 2003; Mensah, 1992). 


\section{3 | THE MODEL}

\subsection{The impact of idiosyncratic unlevered risk on structural change}

The idiosyncratic unlevered risk of a firm is the part of risk that depends on both structural characteristics and how some relevant exogenous factors interact with the firm structure. Endogenous factors can be managed to maximize opportunities for growth and improve firms' evolutionary dynamics.

Idiosyncratic unlevered risk is linked to intrinsic business risk. The proxy measure for the latter risk is the revenue volatility. In fact, this volatility is caused by variations in both demand and prices of goods (Chung, 1989; Ross, Westerfield, \& Jaffe, 2002). Specifically, intrinsic business risk can be measured as the standard deviation of expected revenues:

$$
\begin{aligned}
& \mathrm{IBR}=\sqrt{\sum_{i=1}^{n} p_{i}\left(\mathrm{REV}_{i}-\mathrm{REV}^{\prime}\right)^{2}} \\
& \text { with } \mathrm{REV}^{\prime}=\sum_{i=1}^{n} p_{i}\left(\mathrm{REV}_{i}\right)
\end{aligned}
$$

where:

$\mathrm{IBR}=$ intrinsic business risk;

$p_{\mathrm{i}}=$ probability of the ith scenario;

$\mathrm{REVi}=$ revenues in the case of the ith scenario;

REV' = average expected revenues.

The structural characteristics of a firm deeply influence its inbound of intrinsic business risk. Different costs depending on structural factors impact the elasticity of earnings before interest and taxes (EBIT). Thus, they determine the inbound of exogenous risk factors affecting the absorption of intrinsic business risk.

The elasticity of EBIT, also known as the degree of operating leverage (DOL), is measured by the following expression:

$$
\mathrm{DOL}=\frac{\Delta \mathrm{EBIT}}{\mathrm{EBIT}_{\text {to }}} \cdot \frac{\mathrm{REV}_{t 0}}{\Delta \mathrm{REV}}
$$

Among other costs, fixed costs are the most relevant because they determine either the elasticity or rigidity of the structure.

Consequently, DOL can also be measured with the following expression:

$$
\mathrm{DOL}=1+\frac{\mathrm{FC}_{\mathrm{to}}}{\mathrm{EBIT}_{\mathrm{to}}}
$$

where FC represents fixed costs.

Equation (3) is equal to equation (1) when, over time, all factors are constant but the demand for goods, which is variable. Equation (3) allows us to predict the potential impact of demand volatility on EBIT. Once the above conditions are verified, the unlevered idiosyncratic risk can also be calculated as the volatility of return on investment (ROI) due to the interrelation between the intrinsic business risk and the level of DOL (Renzi, Sancetta, \& Orlando, 2015):

$$
\sigma_{u}=\sqrt{\mathrm{ROI}_{\mathrm{to}}^{2} \cdot\left(\frac{\mathrm{IBR}}{\mathrm{REV}}\right)_{t 0}^{2} \cdot\left(1+\frac{\mathrm{FC}_{\mathrm{tO}}}{\mathrm{EBIT}_{\mathrm{to}}}\right)^{2}}
$$

where:

$$
\begin{aligned}
& \sigma_{u}=\text { idiosyncratic unlevered risk; } \\
& \mathrm{IBR}=\text { intrinsic business risk; } \\
& \mathrm{FC}=\text { fixed costs. }
\end{aligned}
$$

Equation (4) is based on the bottom-up logic, by which the idiosyncratic risk is determined by firm-specific characteristics (Banz, 1981; Beneda, 2003; Conine, 1980, 1982; Hamada, 1972).

In particular, equation (4) underscores the influence of firm costs on idiosyncratic unlevered risk. For instance, a high level of fixed costs is both a threat and an opportunity because it can increase the overall level of firm risk. However, it can also be due to scale economies, which represent a competitive advantage.

The twofold effect of operating leverage on performance disappears as soon as strategic decisions, on both the size of the firm and its endowment of resources and capabilities, are made. We refer to instability for this transition phase. When a firm adopts a new technology, this could impact the size and typology of costs. Therefore, in the absence of structural changes, given the intrinsic business risk of the firm, the idiosyncratic unlevered risk depends on the endowment of resources and how they affect the operating leverage. In contrast, in cases of structural change, the idiosyncratic risk depends on the temporal mismatch between new fixed costs and the dynamic of revenues. The current model assumes that the structure largely affects firm risk. Thus, we adopt and extend the bottom-up model proposed by Renzi, Sancetta, and Orlando $(2013,2015)$. Further details on this model are provided in the Appendix.

Specifically, we assume that the idiosyncratic unlevered risk depends on fixed costs to net investments (FC), and on the contribution margin (CM), which is given by total revenues minus total variable costs, to net investments. Thus, we measure the two different coefficients as follows:

$$
\begin{aligned}
& \theta_{\mathrm{j}}=\frac{\mathrm{CM}_{\mathrm{j}}}{\mathrm{NI}_{j}} \\
& \mu_{\mathrm{j}}=\frac{\mathrm{FC}_{\mathrm{j}}}{\mathrm{NI}_{j}}
\end{aligned}
$$

The volatility of each coefficient arises as a positive source of $\mathrm{ROI}$ volatility during the structural change. However, the interplay between them, expressed as their covariance, has a negative effect on risk. Consequently, the ultimate effect is twofold. Specifically, the unlevered risk can be measured with the following expression:

$$
\sigma_{j(u)}=\sqrt{\sigma_{\theta j}^{2}+\sigma_{\mu j}^{2}-2 \cdot \sigma_{\theta j, \mu j}}
$$

where:

$\sigma_{\theta j}=$ standard deviation of $\theta$;

$\sigma_{\mu j}=$ standard deviation of $\mu$;

$\sigma_{\theta j, \mu j}=$ covariance between $\theta j$ and $\mu \mathrm{j}$. 
In dynamic conditions and during structural instability, the idiosyncratic unlevered risk is negatively related to the correlation between $\theta j$ and $\mu j\left(\sigma_{\theta j, \mu j}\right)$. In particular, when they are positively related, the ROI volatility is smaller than the sum between the standard deviation of $\theta j\left(\sigma_{\theta j}\right)$ and of $\mu j\left(\sigma_{\mu}\right)$. When they are negatively related, the idiosyncratic unlevered risk is greater than the above sum. Given the value of the sum $\sigma_{\theta j}+\sigma_{\mu}$, the minimum level of idiosyncratic unlevered risk is reached when the value of the correlation coefficient between $\theta j$ and $\mu j\left(\rho_{\theta j, \mu j}\right)$ is equal to one, for $\rho_{\theta j, \mu j}=+1$ and $\sigma_{\theta j}=\sigma_{\mu j}$.

We propose a further ratio, $\xi$, which aims to both facilitate crosstemporal and inter-firm comparability and explain the effect on the risk of correlation between the two coefficients. It can be measured with the following expression:

$$
\xi=\rho_{\theta j, \mu j} \min \left(\sigma_{\theta j} \sigma_{\mu j}\right) / \max \left(\sigma_{\theta j} \sigma_{\mu j}\right) ;-1 \leq \xi \leq+1
$$

where:

$\min \left(\sigma_{\theta j}, \sigma_{\mu j}\right)=$ minimum value between $\sigma_{\theta j}$ and $\sigma_{\mu j}$; $\max \left(\sigma_{\theta j}, \sigma_{\mu j}\right)=$ maximum value between $\sigma_{\theta j}$ and $\sigma_{\mu j}$.

The idiosyncratic unlevered risk is inversely related to $\xi$. When the latter increases, the risk diminishes, and vice-versa.

The above considerations shed light on the relationship between the idiosyncratic unlevered risk and the structural characteristics of a firm, considering both static and dynamic states.

We use the described bottom-up model to draw four organizational configurations. We distinguish the static state in the absence of structural change and the dynamic state when there are conditions of structural instability. Furthermore, we consider the impact of resource slack on risk. To this end, we compare the firm's DOL with the average $\mathrm{DOL}$ in the sector by using the following expressions:

$$
\lambda_{j}=\frac{\mathrm{DOL}_{j}}{\mathrm{DOL}_{s}}
$$

where:

$\mathrm{DOL}_{j}=$ the degree of operating leverage of the firm;

$\mathrm{DOL}_{s}=$ the average degree of operating leverage in the sector;

$$
\chi_{j}=\frac{\xi_{j}}{\xi_{s}}=\frac{\rho_{\theta j, \mu j}}{\rho_{\theta s, \mu s}} \cdot \frac{\min \left(\sigma_{\theta j}, \sigma_{\mu j}\right)}{\max \left(\sigma_{\theta j}, \sigma_{\mu j}\right)} \cdot \frac{\max \left(\sigma_{\theta s}, \sigma_{\mu s}\right)}{\min \left(\sigma_{\theta s}, \sigma_{\mu s}\right)}
$$

where:

$\xi_{j}=$ the correlation coefficient between $\theta$ and $\mu$ of the firm;

$\xi_{s}=$ the correlation coefficient between $\theta$ and $\mu$ of the sector.

The ratio $\lambda_{j}$ expresses the firm's relative degree of operating leverage. The latter ratio, $\chi_{j}$, equation, allows the comparison between the firm and the sector in relation to $\xi_{j}$. The comparison between $\lambda_{j}$ and $\chi_{j}$ helps us to understand the sources of risk and how to leverage growth, managing the static and dynamic states.

In general, $\lambda_{j}$ identifies the type of risk closely linked to internal resources that were gathered through past investments. From this point of view, $\lambda_{j}$ shows in relative terms that part of the idiosyncratic unlevered risk due to operative slack, which is a source of DOLj. In contrast, $\chi_{j}$ explains the firm-specific risk in cases of change, and it has a negative correlation with the risk itself.

\section{2 | The two-state matrix for managerial decisions}

The DNA of the firm is represented by its specific structure. In the short run or during the exploitation and static phase, it is assumed to be invariable, in the sense that the firm has a constant endowment of resources and capabilities. At the organizational structure level, the specificity of the firm configuration is due to the sticky interaction between resources and capabilities. This combination of initial endowment of resources and capabilities and the way they interact with each other over time in a unique manner exactly represents the DNA of the firm. This means that each firm has a specific risk and absorbs environmental risk differently from its competitors. Assuming an evolutionary and path-dependent perspective, we argue that organizational configurations influence the odds of survival, future profitability, and paths of development.

Based on the above considerations, we propose a matrix that synthesizes four different organizational configurations, characterized by alternative effects of firm structure on idiosyncratic unlevered risk. In each configuration, we distinguish a static from a dynamic state. The matrix has two dimensions: (i) $\lambda_{j}$, the firm's degree of operating leverage compared with that of the sector; and (ii) $\chi_{\mathrm{j}}$, the firm's structural volatility compared with that of the sector. The latter coefficient depends on the correlation between the volatility of the two coefficients, $\theta$ and $\mu$. The four organizational configurations are characterized likewise by risk patterns over time and different endowments of resource slack. The matrix is depicted in Figure 1.

The risk patterns are described in Table 1, while the organizational configurations follow in Table 2. The north-west configuration describes those firms that have a combination of a relatively high level of $\lambda$ with a relatively low level of $\chi$.

Investing in this type of firm implies a risk higher than the sector average but also a higher expected return. In this case, managers generally prefer to make conservative decisions and to exploit internal resources as much as possible. This type of configuration is largely affected by volatility in demand, with either positive or negative deviations from the status quo.

A value of $\lambda>1$ could imply either the positive exploitation of scale economies driven by growing demand or losses caused by decreasing demand, in the static state. In the dynamic state, the north-west configuration represents those firms with good capabilities to manage change. The risk level is moderated thanks to $\chi>1$, which means that a variation in fixed costs is timely compensated by a coherent variation in revenues. In such cases, $\lambda>1$ acts as a driver of $\chi>1$. An example could be when the exploitation of the economic potential of a new technology is driven by a slack of technological skills and human resources. Firms belonging to the north-west configuration are able to gather types of slack that are good for development.

The north-east configuration describes firms that have a combination of a relatively high level of $\lambda$ with a relatively low level of $\chi$. These firms are riskier than the average in the sector, in both the 


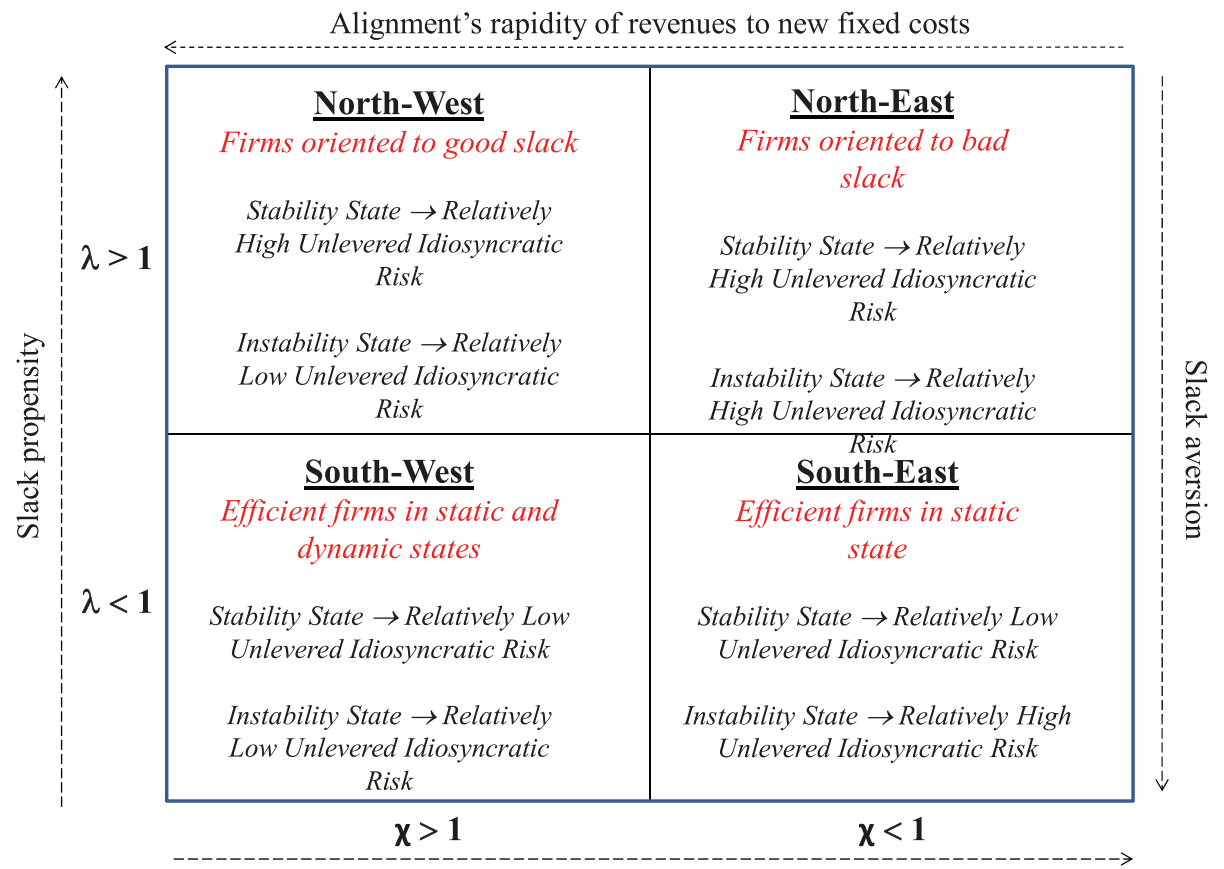

Alignment's slowness of revenues to new fixed costs

FIGURE 1 Organizational configurations and risk patterns

TABLE 1 Risk patterns and organizational configurations

\begin{tabular}{lll} 
Risk pattern per configuration & Static state & Dynamic state \\
\hline North-West & $\begin{array}{l}\text { Relatively high impact of IBR on unlevered idiosyncratic } \\
\text { risk. Internal resources strongly affect the unlevered } \\
\text { idiosyncratic risk in stationary conditions. }\end{array}$ & $\begin{array}{l}\text { Structural volatility has a relatively low impact on unle- } \\
\text { vered idiosyncratic risk. Structural change is a moderator } \\
\text { of idiosyncratic risk in dynamic conditions. }\end{array}$ \\
\hline North-East & $\begin{array}{l}\text { Relatively high impact of IBR on unlevered idiosyncratic } \\
\text { risk. Internal resources strongly affect the unlevered } \\
\text { idiosyncratic risk in stationary conditions. }\end{array}$ & $\begin{array}{l}\text { Structural volatility has a relatively high impact on } \\
\text { unlevered idiosyncratic risk. Structural change amplifies } \\
\text { idiosyncratic risk in dynamic conditions. }\end{array}$ \\
\hline South-West & $\begin{array}{l}\text { Relatively low impact of IBR on unlevered idiosyncratic } \\
\text { risk. Internal resources are a moderator of idiosyncratic } \\
\text { risk in stationary conditions. }\end{array}$ & $\begin{array}{l}\text { Structural volatility has a relatively high impact on } \\
\text { unlevered idiosyncratic risk. Structural change reduces } \\
\text { idiosyncratic risk in dynamic conditions. }\end{array}$ \\
\hline South-East & $\begin{array}{l}\text { Relatively low impact of IBR on unlevered idiosyncratic } \\
\text { risk. Internal resources are a moderator of idiosyncratic } \\
\text { risk in stationary conditions. }\end{array}$ & $\begin{array}{l}\text { Structural volatility has a relatively high impact on } \\
\text { unlevered idiosyncratic risk. Structural change amplifies } \\
\text { idiosyncratic risk in dynamic conditions. }\end{array}$
\end{tabular}

static and dynamic states. The combination between $\lambda>1$ and $\chi<1$ occurs when resource slack inhibits organizational adaptation. Thus, these firms gather more useless slack, which is bad for development because it increases the idiosyncratic unlevered risk in both the static and dynamic states. The latter configuration has a worse risk-return relationship than the first configuration.

From a financial point of view, investments in the latter type of firm are a sub-optimal capital allocation. In the case of the north-east configuration, managers might opt for restructuring strategies-to divest, thus reducing the bad slack.

The south-west configuration refers to firms having a combination of a relatively low level of $\lambda$ and a relatively high level of $\chi$. The structural characteristics of such firms entail greater efficiency than the average in the sector and a small idiosyncratic unlevered risk, in both the static and dynamic states. Thanks to their efficiency, they gather poor slack, and they are also able to be as flexible as needed to timely exploit growth opportunities. However, they also have some weaknesses. The motivation is that efficiency forces the firm to contain the level of fixed costs. Consequently, firms of this type do not pursue economies of scale.

The south-east configuration explains the cases of those firms combining relatively low levels of both $\lambda$ and $\chi$. Indeed, similarly to the previous configuration, they gather poor resource slack, although during phases of structural instability their idiosyncratic unlevered risk is greater than the average in the sector. Their efficiency is limited to the static state. Their poor capability to gather useful slack negatively affects the degree of operating leverage. Thus, they are less risky than competitors in the static phase; however, conversely, they are unable to positively manage change because of idiosyncratic unlevered risk higher than the average in the dynamic phase. In such 
TABLE 2 Risk configurations

\begin{tabular}{|c|c|c|}
\hline Risk configurations & Static state & Dynamic state \\
\hline $\begin{array}{l}\text { Relatively high } \\
\text { stationary risk } \\
\text { Relatively low } \\
\text { innovation risk }\end{array}$ & $\begin{array}{l}\text { This type of firm is committed to change and innovation. High invest- } \\
\text { ment generates a high level of both fixed costs and slack reserves. } \\
\text { Consequently, in static conditions, the firm is more exposed to exter- } \\
\text { nal volatility. The presence of slack somewhat amplifies volatility. }\end{array}$ & $\begin{array}{l}\text { Previous investment leads this type of firm to hold an } \\
\text { incumbent position on the market. The change has a } \\
\text { lower impact on both intrinsic business risk and idiosyn- } \\
\text { cratic unlevered risk. }\end{array}$ \\
\hline $\begin{array}{l}\text { Relatively high } \\
\text { stationary risk } \\
\text { Relatively high } \\
\text { innovation risk }\end{array}$ & $\begin{array}{l}\text { This type of firm is extremely committed to innovation, mostly of the } \\
\text { disruptive type. High investment generates a high level of both fixed } \\
\text { costs and slack reserves. Consequently, in the short run, the firm is } \\
\text { more exposed to external volatility. The presence of slack somewhat } \\
\text { amplifies volatility. }\end{array}$ & $\begin{array}{l}\text { Due to the uncertainty related to innovation, this type of } \\
\text { firm can either succeed or fail. Consequently, in cases of } \\
\text { structural change, it is more vulnerable than a firm in the } \\
\text { previous category and more risky. }\end{array}$ \\
\hline $\begin{array}{l}\text { Relatively low } \\
\text { stationary risk } \\
\text { Relatively low } \\
\text { innovation risk }\end{array}$ & $\begin{array}{l}\text { This type of firm mostly operates in efficiency conditions, in mature } \\
\text { markets, with scarce demand elasticity and/or volatility. Its exposure } \\
\text { to intrinsic business risk is low, and it has poor slack reserves. It } \\
\text { makes few investments in innovation. Often its development is based } \\
\text { on M\&A. }\end{array}$ & $\begin{array}{l}\text { A firm of this type is less exposed than others to the } \\
\text { threat of change. Consequently, structural volatility and } \\
\text { change have a low impact on its idiosyncratic unlevered } \\
\text { risk. }\end{array}$ \\
\hline $\begin{array}{l}\text { Relatively low } \\
\text { stationary risk } \\
\text { Relatively high } \\
\text { innovation risk }\end{array}$ & $\begin{array}{l}\text { This type of firm mostly operates in efficiency conditions, in mature } \\
\text { markets, with scarce demand elasticity and/or volatility. Its exposure } \\
\text { to intrinsic business risk is low, and it has poor slack reserves. It } \\
\text { makes few investments in development and innovation. }\end{array}$ & $\begin{array}{l}\text { This type of firm is the most affected by structural } \\
\text { volatility and change, in terms of idiosyncratic unlevered } \\
\text { risk. The reason can be traced to lack of investment, co- } \\
\text { evolutionary lock-in/lock-out, strategic myopia, and low } \\
\text { propensity for innovation. }\end{array}$ \\
\hline
\end{tabular}

cases, organizational routines might have positive effects during the static phase but can also turn out to be a liability during phases of development. They minimize the waste of resources but do not make strategic investments for growth. Hence, they are not able to timely align the dynamics of both costs and revenues.

Although the matrix is meant to describe general patterns of change, it particularly suits the most emblematic type of change: innovation. Innovation entails structural instability that is more or less intense according to the type of novelty itself. A structure can foster or inhibit innovation, depending on the dynamic of the idiosyncratic unlevered risk. The resource slack markedly alters such risk and the capability to pursue growth.

\section{EXPLORATIVE ANALYSIS}

\section{1 | Method}

Configurations are tested through an explorative analysis on a small set of companies operating in the energy sector. The method adopted is the qualitative comparative analysis (QCA) for fuzzy sets. The literature largely agrees on the viability of this method in strategic studies, due to its ability to explain interdependencies of causal effects among variables and complexity better than traditional statistical analysis based on covariance of factors (Fiss, 2011; Greckhamer, Misangyi, Elms, \& Lacey, 2008; Ragin, 1987, 2000). Moreover, this method particularly fits with the aim of depicting organizational configurations, since "typologies are a unique form of theory building in that they are complex theories that describe the causal relationships of contextual, structural, and strategic factors, thus offering configurations that can be used to predict variance in an outcome of interest" (Fiss, 2011, p. 393). The method also has powerful explanatory power in small set analyses (Mahoney, 2000).
In the current study, we use three main variables to explain configurations. This criterion reduces the fuzziness of the overall frame and further catches those causal relationships that are closer to linearity. Additionally, this method is particularly consistent with the different aims of the article and the characteristics of the investigation. We refer to difficulties in detecting causal relationships and to the extreme complexity of the phenomenon, which could be affected by many other variables.

For the analysis, we use the following procedure: first, we measure the fuzzy truth table algorithm. Then, we set the idiosyncratic unlevered risk as the outcome variable. Causal conditions are represented by $\lambda, \chi$, and the correlation coefficients between the volatilities of the $\theta$ and $\mu$. Then, we delete rows with numbers less than 1 , and set the firm idiosyncratic unlevered risk to 1 for rows with consistency $>0,9$. Finally, we make the standard analysis.

\subsection{Sample characteristics}

The sample is constituted of 11 energy companies, listed on Euronext100. We have extracted economic and financial data for a 5-year period, between 2006 and 2010, using Osiris. We have chosen to focus on a single sector to avoid poor comparability among firms. Moreover, we have selected companies that appear extremely homogeneous in organizational, strategic, and structural terms. The result is a small sample of strongly comparable firms. In fact, all the companies are mostly diversified in a related way, while their non-related diversification degree is nearly zero. Therefore, this specific characteristic allows us to use consolidated data. The decision to investigate the energy sector is also linked to its strategic characteristics. In general, companies operating in the energy market follow a vertical integration pattern. Hence, they have similar structures and are of a similar size.

Using consolidated data, we can compare firms, thanks to their structural isomorphism. Moreover, even if energy companies 
experience extreme volatility in both the price of and the demand for energy, their structure does not undergo extreme changes over time. In fact, the core business continuity is usually verified over decades, and their development is mostly based on the core business expansion strategy.

All these characteristics result in great homogeneity among firms. This condition is ideal to test configurations.

\section{3 | Variables}

First, we measure $\lambda$ and $\chi$ for each year and each firm under consideration, and verify the zero non-related diversification assumption, as stated above, in the sample description. Non-related diversification is measured in terms of entropy (Jacquemin \& Berry, 1979) as follows:

$$
E=\sum_{i=1}^{n} \pi_{i} \ln \left(\frac{1}{\pi_{i}}\right)
$$

where $\pi_{i}$ are the revenues for each operating segment. For sector data, we use the average DOL and the idiosyncratic unlevered risk of the sample itself.

\section{4 | Descriptive statistics}

First, we measure the degree of non-related diversification for each of the 11 companies in the sample. As previously indicated, energy firms mostly invest in related businesses; therefore, their degree of non-related diversification is nearly insignificant (Tables 3 and 4).

TABLE 3 Non-related diversification degree

\begin{tabular}{ll}
\hline Company name & $\begin{array}{l}\text { Non-related diversification } \\
(2006-2010)\end{array}$ \\
\hline EDF & 0.2 \\
\hline EDP & 0.0 \\
\hline EDP RENOVAVEIS & 0.0 \\
\hline FUGRO & 0.0 \\
\hline GALP ENERGIA-NOM & 0.0 \\
\hline GDF SUEZ & 0.2 \\
\hline ROYAL DUTCH SHELLAC & 0.3 \\
\hline SUEZ ENVIRONNEMENT & 0.0 \\
\hline TECHNIP & 0.0 \\
\hline TOTAL & 0.4 \\
\hline VEOLIA ENVIRON. & 0.5 \\
\hline
\end{tabular}

TABLE 4 Descriptive statistics for structural homogeneity of the sample

\begin{tabular}{|l|l|}
\hline Non-related diversification statistics & $(\mathbf{2 0 0 6 - 2 0 1 0 )}$ \\
\hline Average & 0.150342227 \\
\hline Standard error & 0.05679894 \\
\hline Standard deviation & 0.188380772 \\
\hline Sample variance & 0.035487315 \\
\hline Confidence interval 95\% & 0.126555924 \\
\hline
\end{tabular}

Once companies are controlled for homogeneity, we measure the DOL of each of them- using fixed costs and EBIT variables-the standard deviation of $\theta$ and $\mu$, as well as their correlation and covariance. In later calculations, we further use both average data for each single company and the sample average. This latter measure is used as a proxy for sector. After this preliminary phase, we measure the idiosyncratic unlevered risk of each firm and the two variables shown in the matrix, $\lambda$ and $\chi$. Variables, descriptive statistics, and results are reported, respectively, in Tables 5, 6, and 7.

\subsection{Qualitative comparative analysis results}

The truth table output is presented in Table 6, while the standard analysis results are shown in Table 7. The standard analysis explains that the matrix already contains all solutions, both parsimonious and complex, with a frequency and consistency cutoff at 1.000000 .

\section{6 | Discussion}

As the value of $\lambda$ increases, so does the firm risk. The $\lambda$ ratio represents a sort of sensitivity measure of the firm DOL to the sector DOL. However, the greater exposure of the firm to risk, due to structural

TABLE 5 Model variables

\begin{tabular}{lrrlr} 
Company name & \multicolumn{1}{c}{$\chi$} & $\lambda$ & $\begin{array}{l}\text { Idiosyncratic } \\
\text { unlevered risk of } \\
\text { the firm to sample }\end{array}$ & $\begin{array}{l}\text { Average } \\
\text { DOL }\end{array}$ \\
\hline EDF & 1.65 & 0.95 & 0.26 & 2.79 \\
\hline EDP & 32.84 & 0.68 & 0.65 & 1.98 \\
\hline EDP RENOVAVEIS & 0.00 & -0.05 & 0.23 & -0.15 \\
\hline FUGRO & 4.58 & 1.12 & 0.62 & 3.26 \\
\hline GALP & 1.23 & 0.75 & 1.51 & 2.18 \\
ENERGIA-NOM & & & & \\
\hline GDF SUEZ & 0.33 & 0.98 & 5.12 & 2.87 \\
\hline $\begin{array}{l}\text { ROYAL DUTCH } \\
\text { SHELLAC }\end{array}$ & 0.00 & 0.59 & 1.10 & 1.73 \\
\hline $\begin{array}{l}\text { SUEZ } \\
\text { ENVIRONNEMENT }\end{array}$ & 175.89 & 1.69 & 0.14 & 4.94 \\
\hline TECHNIP & 0.00 & 1.40 & 0.23 & 4.08 \\
\hline TOTAL & 0.00 & 0.55 & 1.14 & 1.61 \\
\hline $\begin{array}{l}\text { VEOLIA } \\
\text { ENVIRONMENT }\end{array}$ & 0.00 & 2.34 & 0.00 & 6.84 \\
\hline
\end{tabular}

TABLE 6 Truth table

\begin{tabular}{llllll}
$\chi_{j}$ & $\lambda_{j}$ & $\xi_{j}$ & Number & $\begin{array}{l}\text { Idiosyncratic unlevered } \\
\text { risk of the firm }\end{array}$ & $\begin{array}{l}\text { Raw } \\
\text { consistency }\end{array}$ \\
\hline 0 & 1 & 1 & 3 & 1 & 1.011120 \\
\hline 0 & 0 & 0 & 1 & 1 & 1.008292 \\
\hline 0 & 1 & 0 & 2 & 1 & 1.006490 \\
1 & 1 & 0 & 1 & 0 & 0.348315 \\
\hline 1 & 1 & 1 & 4 & 0 & 0.076739
\end{tabular}




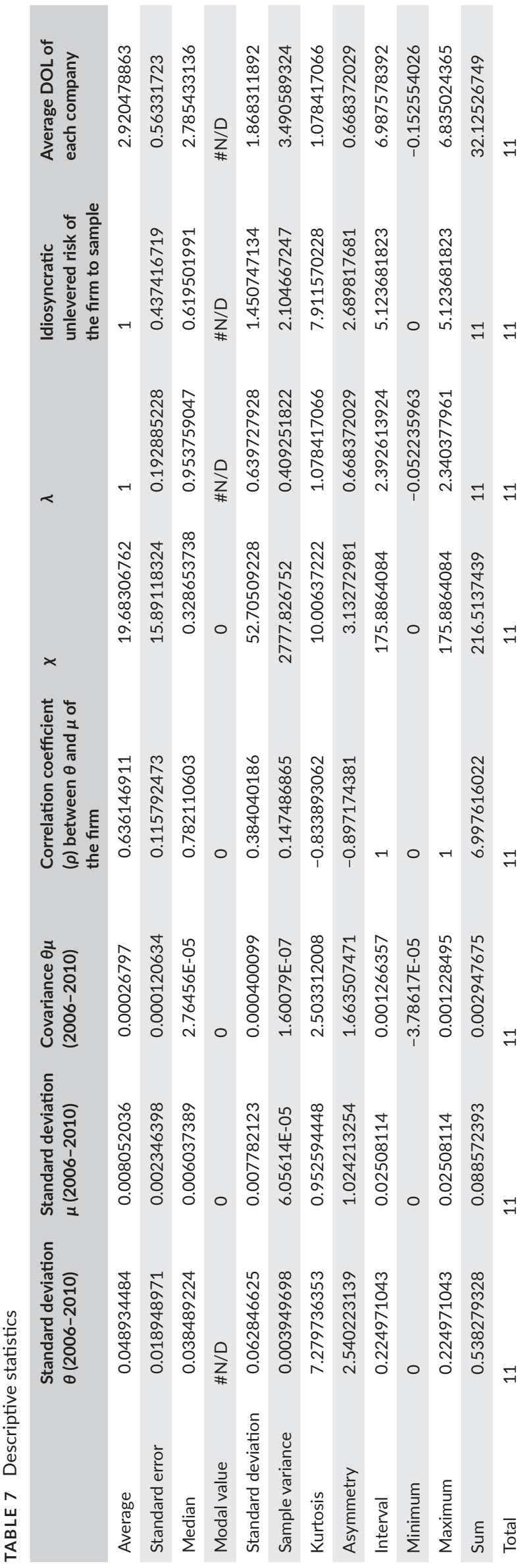

factors, also has a positive side. Most firms take advantage of their structure during instability phases, since they can implement development plans, with a poor impact on their idiosyncratic unlevered risk. Consistently with the model, firms with a low level of $\lambda$ can also have a level of risk greater than the market. In this case, the structure could result in inadequate responses to instability phases. Most companies have a low level of $\chi$, in line with the idea of the negative dynamic between structural instability and risk level. Consistently, for high values of $\chi$, the idiosyncratic unlevered beta dynamic is not influenced by the structure. The explorative test shows the consistency of the model. In fact, we see that the majority of companies have high levels of $\chi$ coupled with low levels of $\lambda$. As stated previously, the south-west configuration corresponds to a condition in which the firm has an idiosyncratic unlevered risk lower than the average in the sector. This is typical of a static competitive environment, such as the energy industry. In contrast, the north-east configuration is extremely influenced by the intrinsic business risk. At the same time, instability phases can markedly alter its level of risk.

The results of QCA, for both complex and parsimonious solutions, show that the matrix contains all possible configurations. Although this depends on how we measure the variables contained in the model, this supports the thesis that the matrix is helpful in depicting different organizational configurations, in terms of risk patterns and structural characteristics. This also demonstrates the validity of causal relationships drawn in the model. Thus, the structure dramatically affects the risk pattern and the firm's ability to manage change. In particular, the QCA confirms causal relationships among $\lambda, \chi$, the correlation coefficients of $\theta$ and $\mu$, and the outcome variable, the idiosyncratic business risk. This result is extremely relevant, despite the small size of the sample, because of the parsimony of variables used. In sum, the three variables have a strong causal relationship to the idiosyncratic unlevered risk, and the relationship can be considered almost linear. This means that testing the model on a larger sample should further confirm the causal interdependence.

\section{5 | MANAGERIAL IMPLICATIONS AND PRACTICAL RELEVANCE}

Notably, the model and the analysis fill a gap in the literature, depicting organizational configurations of the relationship between firm structure and risk in a novel way. The managerial relevance of the matrix can be ascribed to its function: it allows a holistic representation of structural dynamics, risk patterns, and firms' capability to manage change. Additionally, we describe the role played by resource slack in each configuration.

At the practical level, the model and the matrix are easy-to-use tools for decision making. The matrix acts as a shortcut; thus, the configuration can be used as a heuristic for structural decisions in the short and long runs. The model itself allows measuring idiosyncratic business risk in a bottom-up way. In particular, it is relevant in the case of innovation plans, when the levels of both risk and uncertainty are extremely high. Furthermore, the results of the analysis show that the depicted organizational configurations have an inherent coherence. 


\section{6 | CONCLUSIONS, LIMITATIONS, AND SUGGESTIONS FOR FUTURE RESEARCH}

This article attempts to identify organizational archetypes in dynamic terms, from structural contingencies to potential evolutionary patterns, when a firm faces structural instability and change. The results of the analysis seem to support the validity of the model. Thus, the matrix can be a valid tool for the decisionmaking process: it allows both predicting, in fuzzy terms, the evolution of risk, according to contingent structural characteristics, and choosing the best strategy accordingly. The firm's capability to undergo phases of change, facing structural instability, is extremely relevant to its chances of survival, especially when the development is based on innovation.

As the main constraint in the current analysis, we are aware of the limited size of the sample and the fact that our model requires further and more extensive tests. Future scholars should replicate the test on large-scale samples. Additionally, the model solely focuses on a spare set of variables. Other factors might be relevant, such as innovation.

Future studies should increase the complexity of the model, including other relevant variables, such as R\&D expenses, innovation typologies, and firm strategy. Finally, the use of organizational configurations and QCA represents a fresh start and opens up a new way of studying risk patterns in the managerial field.

\section{REFERENCES}

Aiken, M., \& Hage, J. (1968). Organizational interdependence and intraorganizational structure. American Sociological Review, 33, 912-930.

Aldrich, H. E. (1979). Organizations and environments. Palo Alto, CA: Stanford University Press.

Antle, R., \& Eppen, G. D. (1985). Capital rationing and organizational slack in capital budgeting. Management Science, 31(2), 163-174.

Bali, T. G., Cakici, N., Yan, X. S., \& Zhang, Z. (2005). Does idiosyncratic risk really matter? Journal of Finance, 60(2), 905-929.

Banz, R. W. (1981). The relationship between return and market value of common stocks. Journal of Financial Economics, 9(1), 3-18.

Beneda, N. L. (2003). Estimating the cost of capital using bottom-up betas. CPA Journal, 73(5), 66-73.

Berger, P. L., \& Luckmann, T. (1967). The social construction of reality. New York, NY: Doubleday.

Bourgeois, L. J. (1981). On the measurement of organizational slack. Academy of Management Review, 6(1), 29-39.

Bourgeois, L. J., \& Singh, J. V. (1983). Organizational slack and political behavior among top management teams. Academy of Management Proceedings, 83(1), 43-47.

Brown, G., \& Kapadia, N. (2007). Firm-specific risk and equity market development. Journal of Financial Economics, 84(2), 358-388.

Campbell, J. Y., Lettau, M., Malkiel, B. G., \& Xu, Y. (2001). Have individual stocks become more volatile? An empirical exploration of idiosyncratic risk. Journal of Finance, 56(1), 1-43.

Cao, C., Simin, T., \& Zhao, J. (2008). Can growth options explain the trend in idiosyncratic risk? Review of Financial Studies, 21(6), 2599-2633.
Carroll, C., \& Wei, K. C. J. (1988). Risk, return, and equilibrium: An extension. Journal of Business, 61, 485-489.

Chan, K. C., \& Chen, N. (1988). An unconditional asset pricing test and the role of firm size as an instrumental variable for risk. Journal of Finance, 43(2), 309-325.

Cheng, J. L., \& Kesner, I. F. (1997). Organizational slack and response to environmental shifts: The impact of resource allocation patterns. Journal of Management, 23(1), 1-18.

Child, J. (1972). Organizational structure, environment and performance: The role of strategic choice. Sociology, 6(1), 1-22.

Child, J. (1973). Strategies of control and organizational behavior. Administrative Science Quarterly, 18(1), 1-17.

Chung, K. H. (1989). The impact of demand volatility and leverages on the systematic risk of common stocks. Journal of Business Finance and Accounting, 16(3), 343-360.

Clayton, M. C., Hartzell, J. C., \& Rosenberg, J. (2005). The impact of CEO turnover on equity volatility. Journal of Business, 78(5), 1779-1797.

Cohen, M. D., March, J. G., \& Olsen, J. P. (1972). A garbage can model of organizational choice. Administrative Science Quarterly, 17(1), 1-25.

Conine, T. E. (1980). Corporate debt and corporate taxes: An extension. Journal of Finance, 35(4), 1033-1037.

Conine, T. E. (1982). On the theoretical relationship between business risk and systematic risk. Journal of Business Finance and Accounting, 9(2), 199-205.

Cyert, R. M., \& March, J. G. (1963). A behavioral theory of the firm. Englewood Cliffs, NJ: Wiley-Blackwell.

Doty, D. H., Glick, W. H., \& Huber, G. P. (1993). Fit, equifinality, and organizational effectiveness: A test of two configurational theories. Academy of Management Journal, 36(6), 1196-1250.

Ferreira, M. A., \& Laux, P. A. (2007). Corporate governance, idiosyncratic risk, and information flow. Journal of Finance, 62(2), 951-989.

Fiss, P. C. (2007). A set-theoretic approach to organizational configurations. Academy of Management Review, 32(4), 1180-1198.

Fiss, P. C. (2011). Building better causal theories: A fuzzy set approach to typologies in organization research. Academy of Management Journal, 54(2), 393-420.

Freeman, J., Carroll, G. R., \& Hannan, M. T. (1983). The liability of newness: Age dependence in organizational death rates. American Sociological Review, 48, 692-710.

Fu, F. (2009). Idiosyncratic risk and the cross-section of expected stock returns. Journal of Financial Economics, 91(1), 24-37.

Gahlon, J. M., \& Gentry, J. A. (1982). On the relationship between systematic risk and the degrees of operating and financial leverage. Financial Management, 11(2), 15-23.

Gaspar, J. M., \& Massa, M. (2006). Idiosyncratic volatility and product market competition. Journal of Business, 79(6), 3125-3152.

Godfrey, P. C. (2005). The relationship between corporate philanthropy and shareholder wealth: A risk management perspective. Academy of Management Review, 30(4), 777-798.

Goyal, A., \& Santa-Clara, P. (2003). Idiosyncratic risk matters! Journal of Finance, 58(3), 975-1007.

Grant, R. M. (1996). Toward a knowledge-based theory of the firm. Strategic Management Journal, 17(S2), 109-122

Greckhamer, T., Misangyi, V. F., Elms, H., \& Lacey, R. (2008). Using qualitative comparative analysis in strategic management research: An examination of combinations of industry, corporate, and business-unit effects. Organizational Research Methods, 11(4), 695-726. 
Greenwood, R., \& Hinings, C. R. (1993). Understanding strategic change: The contribution of archetypes. Academy of Management Journal, 36(5), 1052-1081.

Griffin, H. F., \& Dugan, M. T. (2003). Systematic risk and revenue volatility. Journal of Financial Research, 26(2), 179-189.

Hamada, R. S. (1972). The effects of the firm's capital structure on the systematic risk of common stocks. Journal of Finance, 27(2), 435-452.

Handa, P., Kothari, S. P., \& Wasley, C. (1989). The relationship between the return interval and betas: Implications for the size effect. Journal of Financial Economics, 23(1), 79-100.

Hill, N., \& Stone, B. (1980). Accounting beta, systematic operating risk, and financial leverage: A risk composition approach to the determinants of systematic risks. Journal of Financial and Quantitative Analysis, 15(3), 595-637.

Hillier, D., Titman, S., \& Grinblatt, M. (1998). Financial market and corporate strategy. Maidenhead: McGraw-Hill.

Irvine, P. J., \& Pontiff, J. (2009). Idiosyncratic return volatility, cash flows, and product market competition. Review of Financial Studies, 22(3), 1149-1177.

Jacquemin, A. P., \& Berry, C. H. (1979). Entropy measure of diversification and corporate growth. Journal of Industrial Economics, 27(4), 359-369.

Jensen, M. C. (1986). Agency cost of free cash flow, corporate finance, and takeovers. American Economic Review, 76(2), 323-329.

John, K., John, T. A., \& Reisman, H. (1994). Accounting data and asset valuation: Theory. Review of Quantitative Finance and Accounting, 4(4), 311-320.

Kaldor, N. (1955). Alternative theories of distribution. Review of Economic Studies, 23(2), 83-100.

Ketchen, D. J., Thomas, J. B., \& Snow, C. C. (1993). Organizational configurations and performance: A comparison of theoretical approaches. Academy of Management Journal, 36(6), 1278-1313.

Ketchen, D. J., Combs, J. G., Russell, C. J., Shook, C., Dean, M. A., Runge, J., \& Beckstein, B. A. (1997). Organizational configurations and performance: A meta-analysis. Academy of Management Journal, 40(1), 223-240.

Lee, D. D., \& Faff, R. W. (2009). Corporate sustainability performance and idiosyncratic risk: A global perspective. Financial Review, 44(2), 213-237.

Mahoney, J. (2000). Strategies of causal inference in small- $N$ analysis. Sociological Methods \& Research, 28(4), 387-424.

Mandelker, G. N., \& Rhee, S. G. (1984). The impact of the degree of operating leverage and financial leverage on systematic risk of common stock. Journal of Financial and Quantitative Analysis, 19(1), 45-57.

Mazzucato, M., \& Tancioni, M. (2008). Innovation and idiosyncratic risk: An industry-and firm-level analysis. Industrial and Corporate Change, 17(4), 779-811.

Mensah, Y. M. (1992). Adjusted accounting beta, operating leverage and financial leverage as determinants of market beta: A synthesis and empirical evaluation. Review of Quantitative Finance and Accounting, 2(2), 187-203.

Meyer, A. D., Tsui, A. S., \& Hinings, C. R. (1993). Configurational approaches to organizational analysis. Academy of Management Journal, 36(6), 1175-1195.

Miller, D. (1987). The genesis of configuration. Academy of Management Review, 12(4), 686-701.

Miller, D. (1990). Organizational configurations: Cohesion, change, and prediction. Human Relations, 43(8), 771-789.
Mintzberg, H. (1979). The structuring of organizations (Vol.203). Englewood Cliffs, NJ: Prentice Hall.

Moores, K., \& Yuen, S. (2001). Management accounting systems and organizational configuration: A life-cycle perspective. Accounting, Organizations and Society, 26(4), 351-389.

Moses, O. D. (1992). Organizational slack and risk-taking behaviour: Tests of product pricing strategy. Journal of Organizational Change Management, 5(3), 38-54.

Nohria, N., \& Gulati, R. (1996). Is slack good or bad for innovation? Academy of Management Journal, 39(5), 1245-1264.

Nohria, N., \& Gulati, R. (1997). What is the optimum amount of organizational slack? A study of the relationship between slack and innovation in multinational firms. European Management Journal, 15(6), 603-611.

O'Brien, T. J. (2011). Managerial economics and operating beta. Managerial and Decision Economics, 32(3), 175-191.

Panousi, V., \& Papanikolaou, D. (2012). Investment, idiosyncratic risk, and ownership. Journal of Finance, 67(3), 1113-1148.

Pinto, J. C., \& Curto, J. D. (2007). The organizational configuration concept as a contribution to the performance explanation: The case of the pharmaceutical industry in Portugal. European Management Journal, 25(1) 60-78.

Pondy, L. R. (1970). Toward a theory of internal resource allocation. In M. N. Zald (Ed.), Power in organizations (pp. 270-311). Nashville, TN: University of Vanderbilt Press.

Pontiff, J. (2006). Costly arbitrage and the myth of idiosyncratic risk. Journal of Accounting and Economics, 42(1), 35-52.

Prigogine, I., \& Stengers, I. (1984). Order out of chaos. New York: Bantam.

Quinn, R. E., \& Rohrbaugh, J. (1983). A spatial model of effectiveness criteria: Towards a competing values approach to organizational analysis. Management Science, 29(3), 363-377.

Ragin, C. C. (1987). The comparative method: Moving beyond qualitative and quantitative strategies. Berkeley, CA: University of California Press.

Ragin, C. C. (2000). Fuzzy-set social science. Chicago, IL: University of Chicago Press.

Renzi, A. (2011). Slack organizzativo, rischio e opzioni reali. Padova: Cedam.

Renzi, A., Sancetta, G., \& Orlando, B. (2013). The unlevered systematic risk analysis: A new bottom up approach. Proceedings of European Business Research Conference, Rome, pp. 124-153.

Renzi, A., Sancetta, G., \& Orlando, B. (2015). Unlevered systematic risk, operating leverage, and structural instability: A theoretical approach from a managerial perspective. In G. Sancetta \& D. Strangio (Eds.), Italy in the European context. New perspective of research in economics, environment (pp. 124-153). London: Palgrave.

Ross, S. A., Westerfield, R. W., \& Jaffe, J. (2002). Corporate finance (6th edn) Boston, MA: Irwin/McGraw-Hill.

Rubinstein, M. E. (1973). A mean-variance synthesis of corporate financial theory. Journal of Finance, 28, 167-182.

Seifert, B., Morris, S. A., \& Bartkus, B. R. (2004). Having, giving, and getting: Slack resources, corporate philanthropy, and firm financial performance. Business \& Society, 43(2), 135-161.

Sharfman, M. P., Wolf, G., Chase, R. B., \& Tansik, D. A. (1988). Antecedents of organizational slack. Academy of Management Review, 13(4), 601-614.

Singh, J. V. (1986). Performance, slack, and risk taking in organizational decision making. Academy of Management Journal, 29(3), 562-585.

Thompson, J. D. (1967). Organizations in action. New York, NY: McGraw-Hill. 
Tuli, K. R., \& Bharadwaj, S. G. (2009). Customer satisfaction and stock returns risk. Journal of Marketing, 73(6), 184-197.

Vos, E. A. (1992). Differences in risk measurement for small unlisted businesses. Journal of Small Business Finance, 1(3), 255-267.

Wernerfelt, B. (1984). A resource-based view of the firm. Strategic Management Journal, 5(2), 171-180.

\section{AUTHOR BIOGRAPHY}

Antonio Renzl is a chartered accountant and Professor of Business Management and Entrepreneurship and New Ventures Finance. His current research interests are in real options, open innovation, the risk-return relationship, organizational slack, and entrepreneurship.

GiUSEPPE SANCETTA is a chartered accountant and Professor of Business Management and Corporate Restructuring. His current research

The unlevered risk can be calculated as the standard deviation of the ROI:

$$
\begin{aligned}
& \sigma_{u}=\sqrt{\sum_{i=1}^{n} p_{i}\left(\mathrm{ROI}_{i}-\mathrm{ROI}^{\prime}\right)^{2}} \\
& \text { with } \mathrm{ROI}=\frac{\mathrm{EBIT}}{\mathrm{NI}} ; \quad \mathrm{ROI}^{\prime}=\sum_{i=1}^{n} p_{i}\left(\mathrm{ROI}_{i}\right)
\end{aligned}
$$

where:

$\mathrm{NI}=$ net investment;

$\sigma_{u}=$ unlevered risk in terms of ROI volatility.

The result of equation (A1) can be obtained by recombining the IBR and DOL equations. In particular, assuming that fixed costs, net investment, and the contribution margin per sale (price per sales unit interests are in firm performance, corporate restructuring, risk, and innovation.

Beatrice Orlando is a chartered accountant and Adjunct Professor of Health Management in UNINT, Rome and Strategies for Business Growth in Sapienza University of Rome. Her current research interests are in innovation, decision making, slack resources, and risk.

How to cite this article: Antonio Renzi, Giuseppe Sancetta and Beatrice Orlando. Risk patterns, structural characteristics, and organizational configurations. Strategic Change. 2017;26: 387-397. https://doi.org/10.1002/jsc.2138

less variable cost per sales unit) are all constant during the period, we obtain:

$\sigma_{u}=\frac{\mathrm{IBR}}{\mathrm{REV}_{t 0}} \cdot \sqrt{\left(\mathrm{DOL}_{t 0} \cdot \mathrm{ROI}_{t 0}\right)^{2}}=\frac{\mathrm{IBR}}{\mathrm{REV}_{t 0}} \cdot \sqrt{\left[\left(1+\frac{\mathrm{FC}_{t 0}}{\mathrm{EBIT}_{t 0}}\right) \cdot \mathrm{ROI}_{t 0}\right]^{2}}$

The unlevered risk has an impact on the initial level of ROI that is equal to the operating leverage multiplied by the ratio between the IBR and the revenues in the initial period:

$$
\sigma_{u}^{\prime}=\frac{\sigma_{u}}{\sqrt{\mathrm{ROI}_{t 0}^{2}}}=\frac{\mathrm{IBR}}{\mathrm{REV}_{t 0}} \cdot \sqrt{\mathrm{DOL}_{t 0}^{2}}=\frac{\mathrm{IBR}}{\mathrm{REV}_{t 0}} \cdot \sqrt{\left(1+\frac{\mathrm{FC}_{t 0}}{\mathrm{EBIT}_{t 0}}\right)^{2}}
$$

where:

$\sigma_{u}^{\prime}=$ relative unlevered risk. 
Dear Author,

\section{AUTHOR QUERY FORM}

During the preparation of your manuscript for publication, the questions listed below have arisen. Please attend to these matters and return this form with your proof.

Many thanks for your assistance.

\begin{tabular}{|l|l|c|}
\hline $\begin{array}{l}\text { Query } \\
\text { References }\end{array}$ & Query & Remarks \\
\hline AQ1 & $\begin{array}{l}\text { Baker and Cullen (1993) cited in the text but not listed in the references. Please } \\
\text { give details }\end{array}$ & \\
\hline
\end{tabular}




\section{Suddivisione delle parti della pubblicazione}

Renzi, A., Sancetta, G., \& Orlando, B. (2017). Risk patterns, structural characteristics, and organizational configurations. Strategic Change, 26(4), 373-383.

I sottoscritti dichiarano che:

pur essendo la suddetta pubblicazione il frutto di impegno e riflessioni comuni, a Antonio Renzi vanno attribuiti i paragrafi 1 e 3 e rispettivi sottoparagrafi, Giuseppe Sancetta vanno attribuiti i paragrafi 2 e 5 e rispettivi sottoparagrafi a Beatrice Orlando vanno attribuiti i paragrafi 4 e 6 rispettivi sottoparagrafi.

Luogo e data

Roma, 08/11/2017

Firme
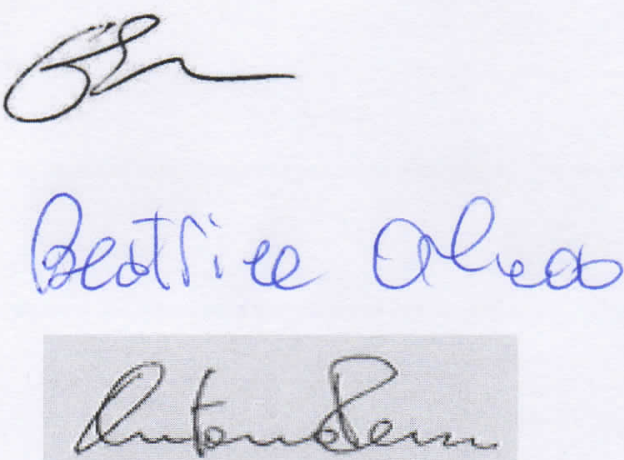

. 